\title{
Attitudes of Medical Malpractice in Pediatric Surgery
}

\section{Çocuk Cerrahisinde Tibbi Malpraktis Tutumu}

\author{
Ahmet Arıkan1, Serkan Çınarlı2, Fisun Şenuzun Aykar3, Ali Sayan4 \\ 1 Private Tınaztepe Hospital, Clinic of Pediatric Surgery, Izmir, Turkey \\ ${ }^{2}$ Celal Bayar University Faculty of Economics and Administrative Sciences Public Administration, Department of Legal Sciences, Manisa, Turkey \\ ${ }^{3}$ Ege University Faculty of Nursing, Department of Internal Medicine Nursing, Izmir, Turkey \\ 4 University of Health Sciences, Tepecik Training and Research Hospital, Clinic of Pediatric Surgery, Izmir, Turkey
}

\section{ABSTRACT}

Aim: The aim of this study was to evaluate the proportion of pediatric surgeons who committed medical malpractice (MM) while on duty in hospitals, whether this proportion changed according to age and experience, and if they reported MM or not, and to determine their level of knowledge related to the legal processes.

Materials and Methods: A cross-sectional survey design was used with a two-part web-questionnaire developed by the authors. The webquestionnaire consisted of twenty-four questions and was prepared after a review of the relevant literature as required to address the aims of the study. Statistical analysis was conducted using SPSS 18.0.

Results: One hundred and fifty-one pediatric surgeons answered the questionnaire; $46 \%$ were specialists, $87 \%$ were working in public hospitals, and $9 \%$ had never committed MM. The type of institution did not affect the occurrence of MM. The major factors that affected the occurrence of MM seemed to be lack of knowledge and experience alongside lack of attention. Working conditions and exhaustion played minor roles. While junior pediatric surgeons mostly committed MM in abdominal, urogenital, newborn and thoracic surgeries, the area was mostly newborn surgery for senior surgeons. Conclusion: Few MM cases were taken to court. Lack of experience, knowledge and attention play major roles in the occurrence of MM. MM cases should be archived meticulously.

Keywords: Medical malpractice, medical ethics, pediatric surgery
ÖZ

Amaç: Bu çalışmanın amacı hastanelerde görev yapan çocuk cerrahlarının tıbbi malpraktise (MM) karışma oranları, MM oranlarının yaş ve deneyim ylıı ile ilgili olup olmadığı, tıbbi hata durumlarıı raporlayıp raporlamadıkları ve yasal süreç hakkındaki bilgi düzeylerine yönelik oranları saptamaktır.

Gereç ve Yöntemler: Araştırmacılar tarafindan oluşturulan iki bölümlü web tabanlı soru formu ile verilerin toplandığı kesitsel bir çalışmadır. Web tabanlı anket, yirmi dört sorudan oluşmakta ve çalışma amacına yönelik olarak ilgili literatürün incelenmesi ile elde edilmiştir. Tüm istatistiksel analizler SPSS 18.0 kullanılarak yapılmışıtı.

Bulgular: Yüz elli bir çocuk cerrahı anketi cevaplamıştır. Cevaplara göre; \%46'sı uzman, \%87'si kamu hastanelerinde çalısııyor ve \%9'u da hiç MM yaşamamıştır. Kurum türü, yaş ve deneyim MM oluşumunu etkilememektedir. Kıdemsiz çocuk cerrahları çoğunlukla abdominal, ürogenital, yenidoğan ve göğüs cerrahisinde MM oluştururken, kıdemli cerrahlar çoğunlukla yenidoğan cerrahisinde MM gerçekleştirmiştir. MM oluşumunu etkileyen başlıca faktörler bilgi ve deneyim eksikliğidir. Iş koşulları ve bitkinlik küçük roller oynamaktadır. Dikkat eksikliği de başarııı etkilemektedir.

Sonuç: Birkaç MM olgusu mahkemeye taşınmıştır. MM oluşumunda deneyim, bilgi ve dikkat eksikliği önemli rol oynamaktadır. MM olguları dikkatli bir şekilde arşivlenmelidir.

Anahtar Kelimeler: Tıbbi malpraktis, tıbbi etik, çocuk cerrahisi 


\section{Introduction}

Medical malpractice ( $\mathrm{MM}$ ) is a multi-faceted subject, which has been discussed in terms of its legal, ethical, and medical aspects particularly in developed countries in the last 30 years, and recently in Turkey. Malpractice is any act by a physician or any other healthcare provider who deviates from accepted norms of practice and causes injury to the patient (1). The World Medical Association defined malpractice as a loss incurred during the medical practice of a physician by "not performing the standard and current practice", "neglecting patients and not providing them with treatment", or "lack of skill". It is defined by the Turkish Medical Association's Code of Professional Ethics as "an injury to a patient because of ignorance, inexperience or negligence, and improper medical performance" (2).

Countries have different systems to address malpractice. For instance, in Greece, Spain, Thailand and the U.S., malpractice cases are handled in civil courts (3). Other countries like Sweden, New Zealand, and France have a somewhat different malpractice system. In these countries, civil courts do not handle malpractice cases, and physicians are not as deterred from committing medical errors because accused physicians there do not have to spend as much time and money on court appearances and legal fees (3).

In Turkey, the concept of malpractice was defined by the Draft Law on Liability Arising from Medical Malpractice in 2002. This legislation tried to solve the subject of civil liability compensation by imposing the requirement of professional liability insurance. The law is based on the liability of health institutions and organizations. On the other hand, it brought into question the probability that joint liability be also allocated to medical personnel who will conditionally have full responsibility (4).

In its report, "to err is human", the Institute of Medicine states that the problem of $\mathrm{MM}$, and preventable, undesired incidents which result in risks for patient safety increase morbidity and mortality rates, cause deaths more than motor vehicle accidents, breast cancer or AIDS, and are the seventh most common cause of death (5). In a study conducted by Sarıca et al. (6), the death rate due to MM was found to be $81 \%$. However, in studies conducted in developed countries, this rate was reported to be between $18 \%$ and $22 \%(6)$. Although there are no proper and accessible records regarding MM in Turkey, judicial archives, the records of the Supreme Council of Health, and the Institute of Forensic Medicine indicate that the increase in $\mathrm{MM}$ is an undeniable fact. Over the last 15 years, the MM claims have increased by $40-120 \%(7,8)$. Most of these claims involved children. A study conducted by Özkaya (8) reported that of the 1458 $\mathrm{MM}$ claims referred to the Institute of Forensic Medicine, 378 were pediatric cases. Over the last seven years, the rate of increase in $\mathrm{MM}$ claims involving children was found to be 406\% between 2002 and 2006 while population growth was $149 \%$ (8). Facts and figures particular to pediatric surgery cannot be obtained because it is evaluated in the group of general surgery or pediatrics in studies on MM. In Turkey, a study conducted by Çom (9) examined cases that were investigated for MM claims, and the decisions of the Specialized Board of the Institute of Forensic Medicine between 2012 and 2013 according to department. Emergency rooms, gynecology and obstetrics were ranked first and second, respectively. The department of pediatric surgery was ranked seventh among 21 departments (9).

Although many studies of MM have been published in Turkey, the specific experience and attitudes of pediatric surgery have not been addressed.

\section{Purpose}

The aims of the survey were to determine:

1. The proportion of pediatric surgeons who had committed MM while on duty in hospitals,

2. Whether age and experience changed attitudes towards MM, and

3. Whether they reported MM and knew about the legal processes.

\section{Materials and Methods}

A survey design with a cross-sectional method was used to examine the attitudes of pediatric surgeons toward liability, and to examine the relationship among the variables. Our data were based on an e-mail survey conducted in February 2014 of 700 Turkish Pediatric Surgery Association (TPSA) members.

\section{Sample, Instruments and Data Collection}

Data were collected using a two-part web-questionnaire developed by the authors. The first part of the questionnaire solicited socio-demographic data and the second asked about malpractice and legal proceedings. The web-questionnaire consisted of twenty-four questions: yes/no questions, strongly agree-strongly disagree questions, and questions scaled from 1 to 6 . The questionnaire was prepared after a review of the relevant literature as required to address the aims of the study $(3,5,9)$.

Content validity of the questionnaire items was established by a lawyer and a professor of medical law. The survey was sent by means of a web link: https://docs.google. com/forms/d/137Ql60q47BMQ16ZmXehgG8okSJOyMHxoB FGAvLi4iXU/viewform. Repeated e-mailing (2 reminders) achieved a response rate of $21 \%$ (151/700). The survey was conducted by an outside vendor (Google, https:// www.google.com/intl/tr_tr/forms/about/) and administered by the TPSA. The data were anonymized without individual respondent identification. Participation in the survey was voluntary. In order to create a balanced participant profile, the questionnaire was distributed in various ways including the internet, a community space, and in hard copies. 


\section{Statistical Analysis}

Descriptive statistics were used to analyze data for demographic characteristics, level of legal awareness, and attitudes toward duty and liability. Chi-square was used to analyze legal awareness and attitudes according to liability group and demographic background. All statistical analyses were conducted using SPSS 18.0. Findings were deemed statistically significant at a p-value of $<0.05$.

\section{Ethical Considerations}

Ethical approval for this study was obtained from Katip Çelebi University's Ethics Committee (approval number: 116/29.05.2014).

\section{Results}

The mean age of the participants was $44.7 \pm 9.7$ years, and $53 \%$ of the pediatric surgeons were in the $41-55$ age interval, $46 \%$ were specialists, and $44 \%$ were working in state hospitals. Approximately one-third of the participants $(32.4 \%)$ were relatively new in the profession (0-15 years), and $15.3 \%$ of the physicians had more than 31 years of pediatric surgery experience (Table I).

Of the pediatric surgeons $53.4 \%$ were unsure about whether they had committed malpractice or not, and $37.3 \%$ thought that they might commit MM. MM legal investigations were found to be conducted for only $22.6 \%$. Of these respondents $69.2 \%$ reported that only one investigation was conducted for them, $15.3 \%$ reported two investigations while $2.5 \%$ reported that they were under investigation for more than three misconducts. Of the lawsuits 30\%, 25\%, $20 \%$, and $12 \%$ were found to be filed concerning abdominal, urogenital, neonatal and thoracic procedures, respectively. The rate of legal compensation investigations due to $\mathrm{MM}$

\begin{tabular}{|l|l|l|}
\hline \multicolumn{3}{|l|}{ Table I. Demographic and professional characteristics of the sample $(\mathrm{n}=151)$} \\
\hline Characteristic & $\mathbf{n}(\%)$ & Mean ( $\mathbf{S D})$ \\
\hline Age groups & $51(33.8)$ & \\
$20-40$ & $80(53.0)$ & $44.7 \pm 9.7$ \\
$41-55$ & $20(13.2)$ & \\
$56-$ over & & \\
\hline Medical institution & $65(43.0)$ & \\
University hospital & $67(44.0)$ & \\
State hospital & $19(13.0)$ & \\
Private hospital & & \\
\hline Job title & $17(11)$ & \\
Research fellow & $69(46)$ & \\
Specialist & $65(43)$ & \\
Lecturer & & \\
\hline Work experience & $49(32.4)$ & \\
$0-15$ years & $79(52.3)$ & $20.2 \pm 10.3$ \\
16-30 years & $23(15.3)$ & \\
31 or more years $\uparrow$ & \multicolumn{2}{|}{} \\
\hline SD: Standard deviation &
\end{tabular}

was found to be $27.6 \%$, and of the pediatric surgeons $76.9 \%$ reported that they had been involved in a compensation investigation once, and $23.1 \%$ said twice. The rate of disciplinary investigations for MM was found to be $26.6 \%$, and of the pediatric surgeons $82.5 \%$ reported that they had been involved in such investigations once. It was found that of their close colleagues $80.2 \%$ were blamed for MM. The study found that of the MM legal investigations conducted for the colleagues of pediatric surgeons, $28 \%, 22 \%, 20 \%$, $15 \%$ and $6.5 \%$ were filed concerning abdominal, urogenital, neonatal, thoracic and burn-related procedures, respectively.

The rate of taking out additional insurance because of MM probability was just $30 \%$. Of the pediatric surgeons $75.3 \%$ reported that the lawsuits associated with $\mathrm{MM}$ affected physician performance; $83.4 \%$ stated that there should be a course related to Health Law for MM in Faculties of Medicine, and $69.8 \%$ reported the necessity for private specialized courts for MM (Table II).

The causes of MM occurrence were asked to the pediatric surgeons, and they ranked inexperience (43.6\%), inadequate knowledge (39.1\%), lack of attention and care $(20.7 \%)$, inappropriate working conditions (17.4\%), fatigue $(15.5 \%)$, and the high number of cases $(12.6 \%)$ as primary causes (Figure 1).

There was no statistical difference between $\mathrm{MM}$ and age, medical institution and work experience (all $\mathrm{p}>0.05$ ). However, it was found that the young pediatric surgeons (20-40 years old) who had just/recently started working (0-15 years), had a lower level of knowledge about MM (all $\mathrm{p}<0.05)$. The examination of the effect of lawsuits regarding

\begin{tabular}{|c|c|c|c|}
\hline & Yes n (\%) & Unsure n (\%) & No n (\%) \\
\hline The occurrence of MM & $58(37.3)$ & $78(53.4)$ & $15(9.3)$ \\
\hline $\begin{array}{l}\text { Conducting legal criminal } \\
\text { investigation due to MM }\end{array}$ & $34(22.6)$ & - & $117(77.4)$ \\
\hline $\begin{array}{l}\text { Conducting legal compensation } \\
\text { investigation due to MM }\end{array}$ & $39(27.6)$ & - & $112(72.4)$ \\
\hline $\begin{array}{l}\text { Conducting disciplinary } \\
\text { investigation due to MM }\end{array}$ & $40(26.6)$ & - & $111(73.4)$ \\
\hline $\begin{array}{l}\text { Blaming close colleagues } \\
\text { due to MM }\end{array}$ & $121(80.2)$ & - & $30(19.8)$ \\
\hline $\begin{array}{l}\text { The effect of MM lawsuits on } \\
\text { physician performance }\end{array}$ & $113(75.3)$ & $27(18.0)$ & $11(6.7)$ \\
\hline $\begin{array}{l}\text { Taking out additional insurance } \\
\text { because of MM probability }\end{array}$ & $45(30.0)$ & $48(32.0)$ & $58(38.0)$ \\
\hline $\begin{array}{l}\text { The presence of a course } \\
\text { related to health law in faculties } \\
\text { of medicine }\end{array}$ & $126(83.4)$ & $25(16.6)$ & \\
\hline $\begin{array}{l}\text { The need for private specialized } \\
\text { courts for MM }\end{array}$ & $106(69.8)$ & $42(28.2)$ & $3(2.0)$ \\
\hline
\end{tabular}




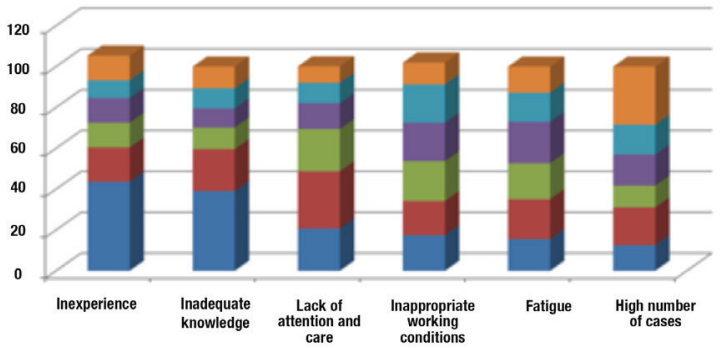

$=6$
$=5$

Figure 1. The ranking of causes affecting medical malpractice in order of significance

MM on physician performance showed that these lawsuits affected the pediatric surgeons who 56 years old and older and had 31-year or more working experience less (all $p<0.05$ ) (Table III).

\section{Discussion}

Although there are many studies conducted on MMs and patient safety in the international literature, the number of studies on this subject is limited in Turkey.

In the present study, of the pediatric surgeons $37.3 \%$ and $53.4 \%$ gave the answers "yes" and "unsure" respectively to the question, "Have you ever made at least one medical error which put patient safety at risk during your working life?", and $80.2 \%$ gave the answer "yes" to the question "Have you ever seen any medical errors made by your teammates, which put patient safety at risk during your working life?". In a study conducted by the Turkish Medical Association on 462 health care workers, 57\% of them answered the question "Have you ever made a medical error during your professional life?" positively (10). No specific study was observed to be conducted for pediatric surgeons in terms of the examination of $\mathrm{MM}$ according to medical specialties. However, in a MM study conducted on medical specialties by Reich and Schatzberg (11) between 2004 and 2011 it was found that although the number of MM lawsuits, which was 3412 per 100,000 population in 2004, decreased to 2434 in 2011, surgeons were involved in the highest number of lawsuits compared to all other areas of specialization. In Turkey, when cases were investigated in terms of MM claim, for which opinions were expressed by the Specialized Board of the Institute of Forensic Medicine between 2012 and 2013 according to departments, emergency, gynecology and obstetrics were ranked first and second respectively. The department of pediatric surgery was ranked seventh among 21 departments (9). The fact that the rates of legal criminal investigation, and legal compensation investigation were found to be $22.6 \%$ and $27.6 \%$, respectively can be regarded as a finding supporting this result.

Most of the pediatric surgeons (69.8\%) reported that there was a need for private specialized courts for MM. In Turkey, the compensation lawsuits for damages incurred due to MMs in public hospitals, foundation hospitals, and state hospitals are handled by administrative courts in administrative jurisdiction while those in private hospitals or clinics are handled by consumer courts as required by law in administrative jurisdiction. This situation is criticized by some because there are differences in terms of procedural law including calling witnesses, holding a hearing etc., and differences between the assessments of these two branches of the judiciary. Also, it was stated that these lawsuits should be heard by private specialized courts under the name of human damages courts without discriminating as administrative or private (10). In our opinion, specialized courts should be established but they should perform their duties as private bodies within both branches of the judiciary.

Table III. Relationship between personal and professional factors and malpractice lawsuits, knowledge and physician performance ( $\mathrm{n=151)}$

\begin{tabular}{|c|c|c|c|c|c|c|c|c|c|}
\hline & & \multicolumn{3}{|c|}{ Malpractice lawsuit } & \multicolumn{2}{|c|}{ Malpractice knowledge } & \multicolumn{3}{|c|}{ Physician performance } \\
\hline & & $\begin{array}{l}\text { Yes } \\
\text { n (\%) }\end{array}$ & $\begin{array}{l}\text { Unsure } \\
\mathrm{n}(\%)\end{array}$ & $\begin{array}{l}\text { No } \\
\text { n (\%) }\end{array}$ & $\begin{array}{l}\text { Yes } \\
\text { n (\%) }\end{array}$ & $\begin{array}{l}\text { No } \\
\text { n (\%) }\end{array}$ & $\begin{array}{l}\text { Yes } \\
\text { n (\%) }\end{array}$ & $\begin{array}{l}\text { Unsure } \\
\text { n (\%) }\end{array}$ & $\begin{array}{l}\text { No } \\
\text { n (\%) }\end{array}$ \\
\hline \multirow{3}{*}{ Age (year) } & $20-40$ & $14(27.5)$ & $31(60.8)$ & $6(11.8)$ & $24(47.1)$ & $27(52.9)$ & $34(68.0)$ & $14(28.0)$ & $3(4.0)$ \\
\hline & $41-55$ & $33(41.0)$ & $39(49.0)$ & $8(10.0)$ & $50(62.5)$ & $30(37.5)$ & $68(85.0)$ & $7(8.0)$ & $5(6.3)$ \\
\hline & $56-$ & $9(45.0)$ & $9(45.0)$ & $2(10.0)$ & $17(85.0)$ & $3(15.0)$ & $11(55.0)$ & $6(30.0)$ & $3(15.0)$ \\
\hline \multicolumn{2}{|l|}{${ }^{*} p$} & \multicolumn{3}{|l|}{0.402} & \multicolumn{2}{|l|}{0.011} & \multicolumn{3}{|l|}{0.010} \\
\hline \multirow[t]{2}{*}{ Medical institution } & University & $25(38.6)$ & $34(52.1)$ & $6(9.3)$ & $40(60.8)$ & $25(39.2)$ & $48(74.6)$ & $11(16.3)$ & $6(7.0)$ \\
\hline & State & $17(25.0)$ & $50(75.0)$ & - & $33(50.0)$ & $33(50.0)$ & - & - & - \\
\hline \multicolumn{2}{|l|}{${ }^{*} p$} & \multicolumn{3}{|l|}{0.396} & \multicolumn{2}{|l|}{0.542} & \multicolumn{3}{|l|}{0.647} \\
\hline \multirow{3}{*}{$\begin{array}{l}\text { Work experience } \\
\text { (year) }\end{array}$} & $0-15$ & $11(22.9)$ & $32(66.7)$ & $6(10.4)$ & $21(42.9)$ & $28(57.1)$ & $32(66.7)$ & 14 (29.2) & $3(4.2)$ \\
\hline & $16-30$ & $35(44.7)$ & $37(47.4)$ & $7(7.9)$ & $51(64.9)$ & $28(35.1)$ & $68(86.3)$ & $7(7.8)$ & $4(3.9)$ \\
\hline & $31-$ & $10(45.5)$ & $10(45.5)$ & $3(9.0)$ & $19(82.6)$ & $4(17.4)$ & $12(52.2)$ & $7(30.4)$ & $4(17.4)$ \\
\hline \multicolumn{2}{|l|}{${ }^{*} p$} & \multicolumn{3}{|l|}{0.152} & \multicolumn{2}{|l|}{0.003} & \multicolumn{3}{|l|}{0.001} \\
\hline
\end{tabular}


The rate of legal compensation investigation due to $\mathrm{MM}$ was found to be $27.6 \%$. The data of the National Practitioner Data Bank in the U.S. stated that 54,099 were obliged to pay compensation as a result of 66,426 lawsuits between 2005 and 2014, and this rate increased over a decade. In a study conducted by Studdert et al. (12), it was stated that according to the reports of the Health Professionals Insurance Association, there was a total of 187 lawsuits involving surgeons who paid compensation in four centers and only 5 of them involved pediatric surgeons. In Turkey, there are no adequate statistical data regarding MM lawsuits and their results. In our opinion, the rate of filing a law suit is high because the damaged patients and their relatives cannot distinguish whether the damage occurred due to a complication or malpractice. Parties should be encouraged to reach an agreement through negotiations before resorting to jurisdiction.

Of the participants $75.3 \%$ responded affirmatively to the question, "Do MM lawsuits or concerns about them affect the service and performance of physicians?". A study conducted by Yıldırım et al. (7) found that they were considered to impair the physicians' health care service by $66.7 \%$. Similarly, Kumral and Özdeş (13) reported that 48\% of the physicians in their study believed the presence of a lawsuit or concerns about one being filed, severely affected their health care service.

The rate of taking out additional insurance because of the likelihood of MM was found to be $30 \%$. In 2009, a study conducted on 112 physicians found that the rate of physicians who had professional liability insurance was $1.7 \%$ (7). The rate of taking out insurance for $\mathrm{MM}$ has since increased considerably. In the European Union, there is no specific arrangement for malpractice insurance. Therefore, each member state has determined the subject with their own national arrangements.

In this study, $83.4 \%$ of the physicians reported that there should be a course on health law in faculties of medicine. In a study conducted by Yıldırım et al. (7), 35.2\% of the physicians as the highest rate, reported that the course subjects regarding malpractice should be taught more intensely in forensic science and deontology courses during medical training for the education provided on the rights and liabilities of physicians to be adequate. Also in a study conducted by Teke et al. (14), 76.1\% of the participants reported that teaching malpractice as a separate subject in the courses of forensic science would be beneficial. The work report of the Turkish Medical Association showed that health care workers have limited knowledge of MM. Those $(17 \%)$ who reported that they received education on this subject during their higher education were graduates of a nursing high school (10). In a study conducted by Kumral and Özdeş (13), 55.8\% of the participants reported that the undergraduate and post-graduate vocational education was inadequate in terms of preventing/decreasing malpractice. Education on these subjects in medical faculties remains inadequate all over the world. Education programs should be planned to enable physicians to learn health law and use this knowledge in their professional lives.

The participants of this study reported that inexperience (43\%) and inadequate knowledge (39\%) were the primary causes of MM, while the health system's inappropriate working conditions and the high number of cases were less important. However, according to Adams and Garber (15), system errors pose more serious problems than errors caused by individuals.

Vural et al. (16) investigated the causes of MM by asking 200 health care workers of whom $75.5 \%$ reported that the errors resulted from multiple error problems and should not be attributed to individuals. In a study conducted by Bodur et al. (17), $55.8 \%$ of the participants and $49.7 \%$ of the healthy individuals stated that institutions and individuals are responsible for MM. A study by Yıldırım et al. (7) found that the most common cause of $\mathrm{MM}$ was "inadequacy in medical education" at the rate of $26.9 \%$. Teke et al. (14) in their study found that the high number of patients receiving daily care and the lack of adequate infrastructure in hospitals were factors that affected $\mathrm{MM}$ at the rates of $89.4 \%$ and $82.4 \%$ respectively.

A study conducted by the Turkish Medical Association revealed the five most important causes as work overload and its effects, insufficient time allocated by physicians to patients, high patient loads in hospitals, inadequate education of the health care workers, and the limited number of nurses (10). The reason inexperience was regarded as the primary cause of MM in this study may be explained by the fact that pediatric surgery is a field where experience is the most important factor.

No statistical difference was found between the occurrence of MM, the amount of knowledge about MM, and the effect of $\mathrm{MM}$ on the performance of the physician in terms of institutions. The fact that pediatric surgery is a new field in Turkey and that a standard education is provided carefully and meticulously in a small number of educational institutions may explain why there was no difference between specialist physicians in state hospitals and university hospitals.

\section{Study Limitations}

Our study was subject to a number of limitations, the major one being the potential for selection bias, with only 151 of 700 pediatric surgeons responding to the survey. Recent malpractice suit involvement was assessed by self-reporting, and we did not distinguish the nature of the litigation (error/delay in diagnosis, failure to treat, etc.), or the number of suits or their outcomes (dismissed, settled, tried to verdict). Selection bias is a limitation of all surveybased investigations, and the similarity between our results and previously published rates suggests that this source of bias did not play a major role in our results. We were not able to detail the major economic concerns of respondents with respect to litigation expenses. The impact of days away from work, practice expenses litigating cases, malpractice 
insurance limits, and increased premiums for malpractice insurance were not addressed in this survey.

\section{Conclusion}

Our results showed that the pediatric surgeons who were young (20-40 years old) and had just started working (0-15 years) had lower levels of knowledge about MM, and that MM lawsuits affected their medical performance more. In their MM study of medical specialties, Jena et al. (18) found that as age and the level of experience in specialties increased, the payments made for MM lawsuits fell.

As a result, $\mathrm{MM}$ is still an important problem which physicians, particularly in surgical branches, will often have to struggle with during their professional lives. A study conducted in the U.S. reported that physicians spent $11 \%$ of their 40-year careers involved in MM lawsuits. Although pediatric surgery was not assessed as a separate branch, the distribution of branches showed that it ranked first among surgical branches.

\section{Ethics}

Ethics Committee Approval: Ethical approval for this study was obtained from Katip Çelebi University's Ethics Committee (approval number: 116/29.05.2014).

Informed Consent: Data were collected using a two-part web-questionnaire developed by the authors. The survey was sent by means of a web link: https://docs.google.com/ forms/d/1370l60q47BMQ16ZmXehgG8okSJOyMHxoBFGAv Li4iXU/viewform. Participation in the survey was voluntary.

Peer-review: Externally peer-reviewed.

\section{Authorship Contributions}

Surgical and Medical Practices: A.A., A.S., Concept: A.A., S.Ç., Design: S.Ç., F.Ş.A., Data Collection or Processing: A.A., A.S., Analysis or Interpretation: S.Ç., F.Ş.A., Literature Search: A.A., S.Ç., F.Ş.A., Writing: F.Ş.A., S.Ç.

Conflict of Interest: No conflict of interest was declared by the authors.

Financial Disclosure: The authors declared that this study received no financial support.

\section{References}

1. Bal BS. An introduction to medical malpractice in the United States. Clin Orthop Relat Res 2009;467:339-47.

2. Çınarlı S. Idarenin Sağlık Hizmetinin Sunumundan Kaynaklanan Hukuki Sorumluluğu. Orion Kitabevi, Ankara, 2013.

3. Creskoff S, Howard M. Medical Malpractice Law "Best Practices" for Jordan: A Preliminary Study with Recommendations for Next Steps. Amman: Jordan: USAID-
Jordan Economic Opportunities Office 2007 Available from http://pdf.usaid.gov/pdf_docs/PNADM752.pdf.

4. Akpinar A, Ersoy N. Attitudes of physicians and patients towards disclosure of genetic information to spouse and first-degree relatives: a case study from Turkey. BMC Med Ethics 2014;15:39.

5. Kohn LT, Corrigan JM, Donaldson MS. Errors in health care: A leading cause of dealth and injury. In: Kohn LT, Corrigan JM, Donaldson MS (eds). To err is human: building a safer health system. Washington, DC: Institute of Medicine National Academy Press, 2000;26-48.

6. Sarıca N, Ertan A, Içmeli Ö, Birgen N, Ovalı F. Çocuk Sağlığı ve Hastalıkları Uzmanlık Alanında Tıbbi Uygulama Hatası Iddiası Bulunan Olguların Adli Tıp Açısından Değerlendirilmesi. Türkiye Klinikleri J Med Sci 2009;29:884-9.

7. Yıldıım A, Aksu M, Çetin I, Şahan AG. Tokat ili merkezinde çalışan hekimlerin tıbbi uygulama hataları ile ilgili bilgi tutum ve davranışları. Cumhuriyet Tıp Derg 2009;31:356-66.

8. Özkaya N. Hekim Dışındaki Sağlık Meslek Mensuplarının Tıbbi Uygulamadan doğan sorumlulukları ve Yüksek Sağlık Şurası Tarafından Hatalı Bulunan Tıbbi Uygulama Örnekleri. Istanbul Barosu, 2011;179-90.

9. Çom U. 2012 ve 2013 Yıllarında Adli Tip Kurumu Birinci Adli Tip İhtisas Kurulu Tarafından Görüş Bildirilen Kadin Hastalıklari ve Doğum Dalında Tıbbi Uygulama Hatası Iddiasi Olgularinin Değerlendirilmesi. Adalet Bakanliği, Adli Tıp Kurumu Başkanliği, Yayınlanmamış uzmanlık tezi, Istanbul, 2015.

10. Sağlık Çalışanlarının Hasta Güvenliği ve Tibbi Uygulama Hataları Ile Ilgili Görüşleri, Hasta Güvenliği: Türkiye ve Dünya. Içinde: Çakmakçı MH, Akalın E). Türk Tabipleri Birliği Yayınları, Ankara, 2011;26-30.

11. Reich J, Schatzberg A. Empirical comparisons of malpractice claims of different specialties. Journal of Public Health Aspects 2015;2:1-7.

12. Studdert DM, Mello MM, Gawande AA, et al. Claims, errors, and compensation payments in medical malpractice litigation. N Engl J Med 2006;354:2024-33.

13. Kumral B, Özdeş T. The Approach and Evaluation of the Doctors in Tekirdag City to the Concept of Malpractice. Int J Basic Clin Med 2013;1:83-93.

14. Teke HY, Alkan HA, Başbulut AZ, Cantürk G. Tibbi Uygulama Hataları ile Illgili Kanuni Düzenlemelere Hekimlerin Bakısı ve Bilgilenme Düzeyi: Anket Çalışması. Türkiye Klinikleri Adli Tıp 2007;4:61-7.

15. Adams JL, Garber S. Reducing medical malpractice by targeting physicians making medical malpractice payments. J Empir Leg Stud 2007;4:185-222.

16. Vural F, Çiftçi S, Fil Ş, Aydın A, Vural B. Sağlık çalışanlarının hasta güvenliği iklimi algıları ve tıbbi hataların raporlanması. Acıbadem Üniversitesi Sağlık Bilimleri Dergisi 2014;5:152-7.

17. Bodur S, Filiz E, Durduran Y. Sağlık personeli ve toplumun tıbbi hatalar ile ilgili görüşlerinin karşılaştırılması. Genel Tıp Dergisi 2011;21:123-30.

18. Jena $A B$, Seabury $S$, Lakdawalla $D$, Chandra A. Malpractice Risk According to Physician Specialty. N Engl J Med 2011;365:629-36. 